\title{
About the Integration of Jewish Literatures into Slavonic Studies
}

\section{Historical Traumas and Academia}

Today, we witness an increased interest in European Jewish culture in general, and in East European Jewry in particular. This greater interest can be seen in different areas of public life, such as cultural events, art, media, but also in the human sciences. In Germany, we can observe an increased presence of Jewish culture in the academic community, particularly: studies of the Jewish diaspora becoming more often a part of philological disciplines such as German, English, Romance and Slavonic Studies. ${ }^{1}$ However, we still have extraordinarily few academic chairs or established degree programs with a focus on research and teaching Jewish "hyphen-areas”, especially beyond German-Jewish Studies. Yiddish Studies and Jewish studies are still perceived as two distinct disciplines, eschewing the contact with studies of other cultures, which in contrast with the very facts of European Jewish history.

Especially in Germany, but to some extent also in East European countries such as Poland, Ukraine and Russia, Jewish studies going beyond the boundaries of their Judaic academic agenda tend to focus on a limited set of subjects, ranging from the annihilation of Jews during the Shoah over antisemitism and the commemoration of Jewish sacrifice, to the topic of loss. The prevalence of these by all means significant subject matters, illustrating the permanent processing of collective historical tragedies, results in the mechanization of Jewish memory and stands in the way of a broader, more creative and balanced approach of Jewish history, culture and especially literature.

Popular interest in Judaism in Europe over the last decades (the so-called Jewish Revival following the historical reappraisal after the fall of the iron curtain) has promoted a rather superficial ethnographic form of acquaintance with Jewish, and especially with the heavily mythologized "Eastern Jewish" cul-

1 A de-essentionalizing, multilingual concept of Jewish literature(s) has been intensely discussed and researched by the international academic community within the last several decades. In this respect, the volume of essays, edited by Hana Wirth-Nesher 1994 and authored by famous writers and scholars (Wirth-Nesher 1994), is particularly interesting.

Ә OpenAccess. ( 2020 Klavdia Smola, published by De Gruyter. (cc))BY-NC-ND This work is licensed under the Creative Commons Attribution-NonCommercial-NoDerivatives 4.0 License. 
ture. ${ }^{2}$ This comes as no surprise after a long period of communist taboo and depression. Today, both historical traumas and nostalgia, especially in Germany and in post-communist East European countries, have an impact on the academic approach of Jewish culture. Reconstruction, catastrophic memory, and revitalization have become key concepts of Judaism. At present, conserving, museumizing strategies and procedures are dominant, also in literary discourse: a (cultural-)historical comment, the tendency towards similarity and reproduction, towards collection, explanation and canonization. It is not without reason that the Holocaust, the process of mourning, memory, and criticism directed at communist oppression are main issues in the works of Polish-Jewish authors such as Henryk Grynberg, Hanna Krall and Piotr Paziński. It is precisely for this reason that the understanding of Judaism in the academic world nowadays requires an unprecedented de-essentializing of the subject matter and an openness towards popular cultures. Meanwhile, in Slavic language "high literatures" too, ever more ironic-subversive and daring techniques and subjects that radically update and challenge memories of Shoah, emerge. In his novel Noc żywych żydów (Night of the living Jews, 2012), Igor Ostachowicz reflects the Shoah by means of multiple allusions to horror films and kitsch, to give but one example.Similarly, in Polish art the multilayered cultural medialisation of Shoah memory has become topicof significant, sometimes provocative works, as for example by Zbigniew Libera or Wilhelm Sasnal. ${ }^{3}$

\section{Academic Institutions, Research and Teaching}

As we can observe by looking at the academic chair of Slavonic-Jewish Studies that was established at Regensburg university some years ago $^{4}$, a set of components is of central importance to the successful integration of Jewish culture and Judaism in the research agendas of other philological disciplines. First of all, there is the incorporation of Slavic-Jewish lectures and seminars in general study programs such as East European studies, study programs with a double degree (bachelor and master) or teacher training in Russian or Ukrainian studies. However, there is need for a study program specifically dedicated to SlavonicJewish Studies, that can be completed aside from other study programs within

2 See Ruth E. Gruber's groundbreaking study on this topic (Gruber 2002). About Jewish Revival in (post-) Communist Russia cf. Smola 2019.

3 Cf. Marszałek 2010.

4 https://www.uni-regensburg.de/sprache-literatur-kultur/slavistik/institut/slavisch-juedischestudien/index.html (3 December 2019). 
the domain of Slavonic philology. In order for such study programs to guarantee a professional double competence for the future, a program of Jewish language courses (in the case of East Europe, Yiddish would even be more important than Hebrew) would be an indispensable part of this. Moreover, language courses within the interdisciplinary program of the respective philological disciplines and (formally) independent of Jewish Studies institutes would be necessary. The formation of Slavonic-Jewish Studies in Regensburg is a rare but already very successful beginning of this politics of scholarly and educational integration in Germany. Nonetheless, even this case did not give birth to an independant "hyphen-area" of education.

The integration of international research collaborations - in particular those involving Jewish diaspora studies in countries such as the US and Israel, where these studies have long left the narrow field of Jewish/Judaic studies and have found an interdisciplinary context at universities - should also be a part of the groundwork in both teaching and research. Conceivable are tandem-events, workshops, joint seminars and the participation of international partners at Slavonic postgraduate schools. Especially the integration of international Jewish studies in postgraduate programs - what has seen an increased institutional significance in recent years - could stimulate the linking of teaching and research in this field: Doctoral students would without a doubt benefit from such initiatives that would allow for an open view of the global Jewish scientific community. As was mentioned before, a pointed collaboration with Jewish institutes and chairs in Germany, aligned with the respective sub-disciplines such as Russian, Polish, Czech or Ukrainian Studies, would be necessary: This would allow for a more in-depth bicultural training, in which the thousand years old religious and cultural history of the Jews as well as Palestine Studies could be productively linked to regional Eastern European Studies.

\section{Jewish Cultural Studies}

Jewish literatures in non-Jewish languages are increasingly incorporated in a broader culture theoretical context. An example of such a context is the spatial turn. As a result of the spatial turn, semantic representations of concepts that are central to Jewish culture and history, such as home and exile, or the relation between the center (Palestine) and the periphery (diaspora), are now again questioned and theoretically substantiated. Recent research also draws upon historical events that have fundamentally altered the concept of Jewish space in East Europe in the twentieth century: the First World War and its subsequent migration waves, the Shoah, Communist regimes with their latent official anti-Semi- 
tism, Zionism and the founding of the state of Israel, the fall of East-European dictatorships and, finally, post-Communist migration flows. Following these developments, there has been a repositioning of Jewish traditional topoi: The Jewish perception of space and concepts such as Makom, Galut, Aliya and the gathering of the dispersed in the Promised Land are amongst others once again dealt with and redefined. ${ }^{5}$

In literary studies, linguistic and poetic interferences and contingencies are seen as the meeting ground where Yiddish, Hebrew and Slavonic writings and identities encounter. These interferences and contingencies draw attention to a desideratum that holds a considerable potential for Slavists. The spatial-topographical side of Jewish Studies today can be integrated with new methodic discussions on transculturality, post-colonialism and cultures of translation or cultural transfer. More traditional conceptions can be tried through the use of new theories.

These and other, similar theoretical shifts have brought about a new focus in the field of Jewish Studies. For instance, phenomena essential to the Jewish Diaspora, such as migration, biculturality and the concept of the border, are merged with postmodern, poststructuralist and postcolonial paradigms, which calls for considerations about categories such as displacement, mimicry, othering and cultural hegemony. As a result of this process, remarkable volumes has appeared, such as Goetschel/Quayson 2016 and Hesse 2016 among others.

\section{Slavonic-Jewish Studies}

The attempts to merge Jewish literatures in different languages into a whole has been described polemically by Dan Miron as "[t]he hunt for an imaginary lost unity of Jewish literature". Instead, he calls for the "acceptance of an inevitable fragmentation" and he postulates "looser, more fluid forms of contact" in a nonhierarchical cultural system” (Miron 2007: 159, 163-166).

As a matter of fact, the "Slavic" component merely refers to similarities concerning political, historical and cultural factors of influence (such as Communism, emigration and the post-dictatorial elimination of official taboos on Jewish interests), as well as the relative simultaneity of artistic reactions to historical deprivations and gaps such as the Holocaust, enforced silence, the call for a

5 In the course of spatial turn and a new interest in Jewish topographies in 2000-2010s, several volumes have been published within the last 10 - 15 years, i.e. Kümper et al. 2007; Lipphardt et al. 2008, and Smola and Terpitz 2014. 
Communist supra-nationalism and the revival of tradition in a post-Communist and postmodern context. At present, for example, these 'contextual analogies' can be analyzed as the symptoms of a posthuman and post-memory culture characterized by similar processes, a culture that largely unfolds in the absence of Jews.

The designation "Slav(on)ic-Jewish" therefore seems rather essentialist in comparison to "East European-Jewish". However, specific linguistic aspects of these literatures can indeed be regarded as essential. First of all, there is the bi- and multilingualism of Jewish authors writing in Ukrainian, Russian or Polish, who were born and socialized between 1910 and 1940, before the start of rigorous assimilation processes due to Sovietization. In many cases, these authors lived in multicultural (peripheral) regions (of which the region of Galicia - a historical region in West Ukraine and South Poland is probably the most wellknown), in which Yiddish and the respective Slavic languages and dialects were mixed. For the Jewish authors, this was a variously weighted double orientation: towards the familiar and religious Jewish tradition on the one hand, and the predominantly Christian, partly Muslim or secular diaspora setting on the other hand. This circumstance affected the polyphony of literary works by such authors as Isaak Babel, Bruno Schulz, Leonid Pervomais'kyi, Ilya Erenburg and Adolf Rudnicki. The authors' double- or multiple rootedness in various languages resulted in the integration of distinct cultural traditions into their work. Precisely through the examples of such authors, forms of hybridity that cross over from the authors' real-life identities onto their unique poetics can be determined, something which has gained wide interest in research over the last years. ${ }^{6}$ It is important to switch from the purely thematic orientation of literary studies, often resulting in some sort of historiographic or ethnographic analysis by means of the text, to the complex relations that constitute the phenomenon of so-called "hyphenated literatures". ${ }^{7}$

To provide a more prominent example, Isaac Babel's works not only belong to the Russian-Ukrainian-Jewish literature because of the fact that they deal with the Odessan Jews' life and fate, but rather also because they combine references to Hebrew holy writings and Yiddish classics with the Russian-Yiddish dialect and the narrative habitus of Russian "high literature" (most notable of Nikolai Gogol'). Babel's ironic, playful way with his readership's multilingualism, his purposeful juggling of subtexts and even the possibility of diverging cultural re-

6 Cf. Koschmal 1997, Grübel 2002, or Sicher 2012.

7 In this context, controversial discussions about the term "Russian-Jewish literature" could be mentioned (see Markish 1995 and Shrayer 2008). 
ceptions (cf. the fitting expression of “double book-keeping” in Sicher 2012: 24) mark a cultural situation that was soon - already in the 1950s - to become unthinkable to Jewish authors in East Europe. Assimilated Jewish authors of the late communist era at best drew their knowledge of Judaism and Yiddish from by then disparate memories and from literature. Babel's subtle differentiation between his readers through connotations and various culturally determined layers of meaning (for example the equation of revolution and messianic redemption) gave way to the commemorating gesture of the idealizing, nostalgic unification of the Jewish world, the homogenizing view from a temporal and a cultural distance. If at all, acculturated authors with Russian, Ukrainian or Polish as their sole literary basis use Yiddish lexical items as an artificial, quoting technique of imitation in the absence of living native speakers. ${ }^{8}$

The example of Babel shows both researchers and students how prominent Jewish authors - in spite of their own literary monolingualism - will remain incomprehensible to a large extent, unless various languages and pretexts are studied. Precisely because of this reason, a collaboration between Jewish, Yiddish and Slavonic Studies would without a doubt be significant and fruitful. It would show that the contact between the disciplines is not a mere addition, but rather a necessary synthesis reflecting the nature of its subject matter.

\section{East European-Jewish Studies}

The boundaries of East European national philological disciplines have recently been pushed and also blurred by the emergence of Jewish literatures on different continents, written in the language of their "host countries" - in English, German, Modern Hebrew or in French. A literary multiculturality emerges, that is still very different from the abovementioned 'classic' Jewish double-rootedness. It is a form of transculturality that entails a post-confessional and highly medialized approach of Judaism - the result of a family history of assimilation or a secondary return to Judaism through readings and geographical reorientation. ${ }^{9}$ There can be no question of a Jewish diaspora here any longer. Israel is an exception: a country in which immigrants from East Europe learn Jewish traditions such as Mishnah, Hasidism or Kabbalah anew. Here, intellectuals, artists and writers more likely discover religious and cultural impulses for their creative ac-

8 In my book (Smola 2019), I analize the specifics of Jewish poetics in the late Soviet and postSoviet prose.

9 Arian Wanner's monograph was one of the first major studies on this kind of heterolingual Jewish literature (cf. Wanner 2011). 
tivities. In other diasporic constellations, however, the Jewish part is hardly recognizable as an ethnic-religious (primordial) culture in and by itself. In texts by such authors as Gary Steyngart, Lena Gorelik and Vladimir Vertlib, Judaism is rather reflected in contemplations on antisemitism and stereotypes; in confessing to the increased dissolution of belonging, and in the attempt to align individual post-memory with the institutionalized cultural memory. These developments, too, bring about new conditions and contexts for both research and teaching. Jewish literary studies thus entail at least three distinct cultural components in this case (that of the country of birth, that of the host country and the Jewish).

Jewish literature of the twentieth and twenty-first century is a multilingual phenomenon par excellence. It will be a real challenge for scholars of today and tomorrow to obtain insight into this complex multicultural field: Comparative studies of Jewish literatures in East Europe are to a large extent still a terra incognita and demand a strong interdisciplinary competence.

\section{Bibliography}

Goetschel, Willi, and Ato Quayson. "Introduction: Jewish Studies and PostcolonialismERRATUM.” The Cambridge Journal of Postcolonial Literary Inquiry, vol. 3, no. 1 (2016): 165-165., doi:10.1017/pli.2015.35.

Grübel, Rainer. “Ein literarischer Messias aus Odessa. Isaak Babel's Kontrafakturen des Chassidismus und der odessitischer Kontext jüdisch-russischer Kultur.” Jüdische Autoren Ostmitteleuropas im 20. Jahrhundert. Ed. Hans H. Hahn and Jens Stüben. Bern: Peter Lang D, 2002. 429-481.

Gruber, Ruth E. Virtually Jewish. Reinventing Jewish Culture in Europe. Berkeley: University of California Press, 2002.

Hesse, Isabelle. The Politics of Jewishness in Contemporary World Literature. The Holocaust, Zionism and Colonialism. London: Bloomsbury Academic, 2016.

Koschmal, Walter. “Kulturbeschreibung aus der Peripherie: Babel's Odessa-Poetik.” Mein Russland. Literarische Konzeptualisierungen und kulturelle Projektionen. Beiträge der gleichnamigen Tagung von 4.-6. März 1996 in München. Ed. Aage A. Hansen-Löve. Bern: Peter Lang D, 1997. 311-336.

Kümper, Michal, Barbara Rösch, Ulrike Schneider, and Helen Thein: Makom. Orte und Räume im Judentum - Real - Abstrakt - Imaginär. Essays. Hildesheim, Zürich, New York: Georg Olms, 2007.

Lipphardt, Anna, Julia Brauch, and Alexandra Nocke. Jewish Topographies. Visions of Space, Traditions of Place. Aldershot: Ashgate Publishing, 2008.

Markish, Shimon. "Russko-evreiskaia literatura: predmet, podkhody, otsenki." Novoe literaturnoe obozrenie 15 (1995): 217-250.

Marszałek, Magdalena. "Anamnesen: Explorationen des Gedächtnisses in der gegenwärtigen polnischen Literatur und Kunst (eine intermediale Perspektive).” Nach dem Vergessen. 
Rekurse auf den Holocaust in Ostmitteleuropa nach 1989. Ed. Magdalena Marszałek and Alina Molisak. Berlin: Kadmos, 2010. 161-171.

Miron, Dan. Verschränkungen. Über jüdische Literaturen. Göttingen: Vandenhoeck \& Ruprecht, 2007.

Shrayer, Maxim D. "In Search of Jewish-Russian Literature: A Historical Overview.” Wiener Slawistischer Almanach 61 (2008): 5-30.

Sicher, Efraim. Babel' in Context. A Study in Cultural Identity. Boston: Academic Studies Press, 2012.

Smola, Klavdia. Wiedererfindung der Tradition: Russisch-jüdische Literatur der Gegenwart. Wien, Köln, Weimar: Böhlau-Verlag, 2019.

Smola, Klavdia, and Olaf Terpitz. Jüdische Räume und Topographien in Ost(mittel)europa. Konstruktionen in Literatur und Kultur. Wiesbaden: Harrassowitz, 2015.

Wanner, Adrian. Out of Russia: Fictions of a New Translingual Diaspora. Evanston, IL: Northwestern University Press, 2011.

Wirth-Nesher, Hana. What is Jewish Literature? Philadelphia, Jerusalem: Jewish Publication Society, 1994. 